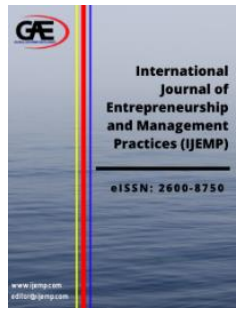

\author{
INTERNATIONAL JOURNAL OF \\ ENTREPRENEURSHIP AND \\ MANAGEMENT PRACTICES \\ (IJEMP) \\ www.ijemp.com
}

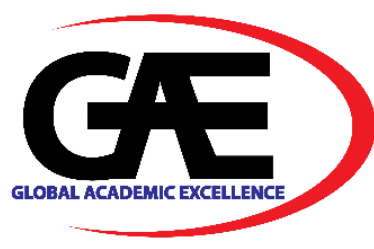

\title{
THE INFLUENCE OF TRANSFORMATIONAL LEADERSHIP ON ORGANIZATIONAL COMMITMENT AND ORGANIZATIONAL CITIZENSHIP BEHAVIOUR (OCB) OF EMPLOYEES AT TERENGGANU'S GOVERNMENT LINKED COMPANIES (GLCS): A CONCEPTUAL FRAMEWORK
}

\author{
Muhammad Al Azzim Mohd Zaki ${ }^{1}$, Juhaizi Mohd Yusof ${ }^{2}$, Nur Aishah Awi ${ }^{3}$ \\ 1 Faculty Business, Economic, Social and Development, Universiti Malaysia Terengganu (UMT), Malaysia \\ Email: alazzimzaki@pps.umt.edu.my \\ 2 Faculty Business, Economic, Social and Development, Universiti Malaysia Terengganu (UMT), Malaysia \\ Email: juhaizi@umt.edu.my \\ 3 Faculty Business, Economic, Social and Development, Universiti Malaysia Terengganu (UMT), Malaysia \\ Email: nuraishah@umt.edu.my \\ Corresponding Author
}

\section{Article Info:}

Article history:

Received date: 11.10 .2021

Revised date: 25.10 .2021

Accepted date: 12.11 .2021

Published date: 01.12.2021

To cite this document:

Zaki, M. A. A. M., Yusof, J. M., \& Awi, N. A. (2021). The Influence Of Transformational Leadership On Organizational Commitment And Organizational Citizenship Behaviour (OCB) Of Employees At Terengganu's Government Linked Companies (GLCS): A Conceptual Framework. International Journal of Entrepreneurship and Management Practices, 4 (16), 01-12.
Abstract:

This study provides a conceptual framework for understanding the impact of transformational leadership on organizational commitment and organizational citizenship behaviour (OCB) among employees in Terengganu's Government Linked Companies (GLCs). In this context, this paper mainly aims at providing a new perspective to understand the occurrence of organizational commitment. It seeks to intrinsically enhance the employees for their discretionary behaviours to the organization's activities. To date, only limited studies are available that consider OCB as a connection developer between transformational leadership and organizational commitment. Organizational commitment is a critical concept with multiple antecedents and implications for organizational performance, goals, employee turnover, and work satisfaction. Employees' commitment to their jobs and organizations is determined by situational and dispositional factors, or by a combination of the two. This study examines how leaders' influences drive employees' OCB and its relationship with organizational commitment. The framework suggests that transformational leadership has a direct influence on organizational commitment and employees' OCB. It is hypothesised that OCB both directly influence and mediate transformational leadership on organizational commitment. 
DOI: $10.35631 /$ IJEMP.416001.

This work is licensed under CC BY 4.0 (a)
Keywords:

GLC, Transformational Leadership, OCB, Organizational Commitment, Employees

\section{Introduction}

The employee is a valuable asset of the organization's antecedents to the success or failure of organizational performance (Hameed \& Waheed, 2011). This phenomenon requires the leaders to consider the necessary retaining who are talented workers in the organization as well as possible (Gupta, Kashyap, Hyde, Lalwani \& Chhabra, 2019) since it increasingly becomes one of the critical issues for organizational leaders nowadays (Gupta et al., 2019), especially for organizations that play a vital role in a country's economic development, including government-linked companies (GLCs). Most of the GLCs in most countries are contributing to their national economy's growth, such as Canada (Boardman, Vining \& Weimer, 2016), China (Gu, Wei \& Cook, 2015), Philippines, Indonesia and Malaysia (Menon, 2017). In Malaysia, Government Linked Companies (GLCs) have been classified as the backbone of its economy (Najid \& Rahman, 2011) and were ranked as the fifth-highest companies in the world trade economy performance (Kowalski, Büge, Sztajerowska and Egeland, 2013), and showed wellmanaged balance sheets (PCG, 2015). In addition, GLCs also have important responsibilities that primarily derive the Malaysian government's commercial objective directly controlled by the board of directors of GLCs (PCG, 2015; Said, Jaafar, \& Atan, 2015; Awani, 2019).

However, the achievement of GLC directors has not been comprehensively examined in which leadership in the GLCs has received less attention, thus leading to less committed employees and impacted GLC's performance in Malaysia, whether at the federal nor state level (Lo, Ramayah, Min \& Songan, 2010; Ishak, 2011; Jamaludin, Sanusi \& Kamaluddin, 2015). For example, Terengganu's GLCs, which the performance in most of them has been labelled less favourable lately required Menteri Besar Terengganu, Dr Shamsuri Mokhtar to decide to close, merge and continue any GLCs companies that are considered no longer contributing to the Terengganu economy (Bernama, 2019). According to Andrew (2017), the importance of commitment among employees highly impact toward the increasing of organizational performance and maintaing it, moreover organizational commitment significantly factor in order to retain an organizational yielding a positive result and achievement of goals (Nordin, 2012; Jones, 2014; Gathungu, Iravo \& Namusonge, 2015).

In addition, the existence of booster facets should include stimulating employee behaviour especially organizational citizenship behaviour (OCB). The culprit does not expect any retaliation for their actions (Alparslan \& Can, 2015). Thus, it is crucial to stimulate their enthusiasm for a job and retain it. According to Hamidi and Salimi (2015), the organization's non-occupational and non-duty activities are important variables in determining the organization's effectiveness. In addition, the organizational pattern encourages good results to the organization and its employees (Ramesh \& Kumar, 2014), primarily through a time of uncertainty that requires a different approach of leadership (Bakar, 2013). This type of leadership style can affect employee commitment (Faupel \& Süß, 2019) and improve the OCB among employees (Rita, Payangan, Rante, Tuhumena \& Erari, 2018). As a result, this study attempts to investigate transformational leadership as a predictor of organizational commitment and organizational citizenship behaviour (OCB) among employees in Terengganu's GLCs. 


\section{Transformational Leadership}

Transformational leadership is indeed a phrase that refers to leaders who are charismatic and visionary in their approach to leading (Woodcock, 2010; Pradhan, Jena \& Bhattacharyya, 2018), which is to please and encourage attitudes among employees and organizational outcomes such as high minds of commitment in the workplace (Yahaya \& Ebrahim., 2016; Allen, Attoh \& Gong, 2017), organization's performance (Gelard et al., 2014), effective management (Buil, Martínez \& Matute, 2019), the creation of an inspirational person to employees' commitment to change (Kit et al., 2015) and spirituality (Asrar-ul-Haq \& Kuchinke, 2016). Leaders can reach an expected organizational achievement by influencing subordinates through inspiring and motivating them in high ideals and goals (Elrehail et al., 2018; Buil et al., 2019) in which the collaboration between employees and leaders is frequently in line with the organization's objectives (Mahmood, 2015; Faupel \& Süß, 2019). According to Masood, Dani, Burns and Backhouse (2006), a transformational leader brings the people together to achieve common goals, and he or she encourages them by showing appreciation, encouraging teamwork and giving special attention to each employee. They can also transform low-key jobs into meaningful work by encouraging employees to engage in innovative behaviours (Bright, 2018; Pradhan \& Jena, 2019). They can spark constructive ideas from employees to their organizations (Wang, Xu, Sun \& Liu, 2019) and transform employees' emotional actions into professional actions to provide the best service for their organization (Luo, Guchait, Lee \& Madera, 2019). This way, leaders can reflect employees' values, goals, and inspirations in line with organizational goals (Lee, Woo \& Kim, 2018). Furthermore, transformational leaders are efficient leaders in executive management in line with current technological developments (Abouraia \& Othman, 2017). In the context of this study, transformational leadership is described as the ability of a leader to examine the demands of his or her employees through motivational and inventive approaches to achieve results.

\section{Organizational Commitment}

Organizational commitment is conceptualised as major pledges towards the achievement of organizational objectives such as high productivity, low employee turnover rate, and the development of a professional work environment (Lin \& Shiqian, 2018; Gupta et al., 2019). Organizational commitment can be defined as individual abilities to impasses their attitudes (Ng \& Feldman, 2011) in a communication process between individuals and organizations, either directly or indirectly (Yao et al., 2019). It is also understood by many researchers as an emotional attachment to an organization's activities, which refers to multi behaviour construct of employees such as earnings, absence and duration of working as well as an essential key to improving their performance in the organization (Shukla \& Pandey, 2019). Organizational commitment can be divided into three main types, namely affective, normative and continuous commitment (Meyer \& Allen, 1990). According to Kuncoro \& Wibowo (2019), affective commitment is the dominant type of organizational commitment of employees. It indicates how far is the employees' confidence level to their organization's effectiveness and performance. Employees' level of commitment to their jobs and the community organization is determined by a combination of situational and dispositional factors, or by a combination of both aspects. In the context of this study, organizational commitment is defined as the emotional attachment of employees to commit to their work and organization in the same direction towards the organization's objectives.

\section{Organizational Citizenship Behaviour (OCB)}

Organizational citizenship behaviours are naturally voluntary engagement by employees involved in any activities to go beyond in-role expectations without any reward claims 


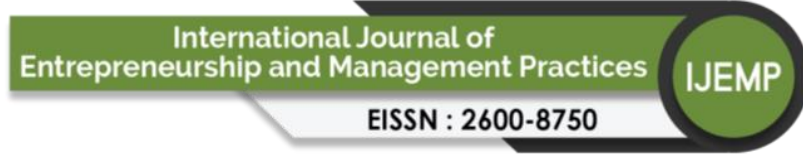

Volume 4 Issue 16 (December 2021) PP. 01-12

DOI: 10.35631/IJEMP.416001

(Whittington \& Galpin, 2010). Organ (1998) stated that OCB is "Individual behaviour that is discretionary, not directly or explicitly recognised by the formal reward system and that in the aggregate promotes the effective functioning of the organization" (Robertson \& Barling, 2017). OCB is the behaviour of workers who contribute to an organization's activities voluntarily and not driven by financial factors (Özduran \& Tanova, 2017; Yu et al., 2018), which is very important in raising interest in work done personally and in organizations (Hamidi \& Salimi, 2015; Yu et al., 2018). Furthermore, OCB can influence employees to cooperate (Zhang, Guo \& Newman, 2017) and be more devoted to ensuring that the social and psychological work environment is conducive to task performance and the organization (Hackett, Wang, Chen, Cheng \& Farh, 2018). OCB refers to the voluntary action beyond their job description (Okeke \& Nnamani, 2018), working on holidays (Hamidi \& Salimi, 2015; Okeke \& Nnamani, 2018), actively involved in non-work activities(Okeke \& Nnamani, 2018), maintaining a conducive working environment(Chen, $\mathrm{Hu}, \&$ King, 2018), encompassing social and psychological aspects (Hackett et al., 2018; Okeke \& Nnamani, 2018) and maintaining organizational's reputation (Chen, Hu \& King, 2018). As highlighted by Organ (2015), the organization can receive a more harmonised environment among the employees from many ways through organizational citizenship behaviour (OCB), including spontaneous help, information sharing and the members' encouragement among employees where an essential source of organizational effectiveness function improves the context of work performance (Montani \& Véronique, 2018; Chen et al., 2018) and enhancing employee's innovation (Chen et al., 2018). In the context of this study, organizational citizenship behaviour (OCB) is defined as the employees' extra behaviour instead of working in ordinary work circumstances and commitment to their organization.

\section{Relationship between Transformational Leadership and Organizational Commitment}

According to numerous prior studies, there is a good relationship between transformative leadership and organizational commitment (Gao, 2011; Kara, 2012; Feizi, Ebrahimi \& Beheshti, 2014; Al Zefeiti, 2017; Buda \& Ling, 2017). When 443 employees in Turkey's fivestar hotel industry were asked about their organizational commitment, Kara (2012) discovered a positive correlation between employee organizational commitment and transformational leadership styles based on five dimensions: idealised attributes, idealised behaviours, inspirational motivation, intellectual stimulation and individual. Transformational leaders have personalities that increase organizational commitment among workers according to research conducted by Selamat, Nordin and Adnan (2013), Njoroge (2015) as well as Buda and Ling (2017). In the education sector, transformational leaders have personalities that increase organizational commitment among educational workers.

The relationship between perceived transformational leadership behaviour and organizational commitment was investigated in another study at an educational construct by Selamat et al. (2013), who looked at 186 secondary school teachers in the district of Klang and examined the relationship between perceived transformational leadership behaviour and organizational commitment. They discovered that secondary school teachers in the Klang district perceived their administrators as exhibiting transformational solid leadership behaviour, which was confirmed by the researchers. In addition, 340 vocational instructors in Jordan were studied by Khasawneh, Omari and Abu-Tineh (2012), who discovered conflicting results in their study of the relationship between transformational leadership and the organizational commitment dimension. The discovery revealed a substantial, positive and statistically significant result in both cases. The principals of the schools, on the other hand, displayed a moderate-to-high level of transformative leadership behaviour. According to the fourth component of the idealised 
influence of transformational leadership's dimensions, vocational teachers in Jordan do not have any impact on their organizations' dedication. A strong effect of transformational leadership style on organizational commitment was discovered by Njoroge (2015) at technical institutions in Kenya, but not when the components of transformational leadership style were considered individually, as was the case previously (idealised influence, individualised consideration and intellectual stimulation). Other findings revealed that inspiring motivation was a significant predictor of affective and normative commitment separately and that it was a significant predictor of all three categories of commitment when considered together (Njoroge, 2015). According to Verma and Krishnan (2013), Porter (2014) as well as Gulluce, Kaygin, Kafadar and Atay (2015), the study in the organization continues to produce inconsistencies in results (2016). Therefore, this study proposed its hypothesis as follows:

\section{$\mathrm{H}_{1}$ : Transformational leadership is positively significant with organizational commitment}

\section{Relationship between Transformational Leadership and Organizational Citizenship Behaviour (OCB)}

Leaders of transformation have characteristics of citizenship behaviour such as altruism, loyalty, sports, welfare and welfare of society (Allen et al., 2017). All these features are apparent when employees are prepared to work outside their scope of work without claiming any official gifts, including additional pay (Han, Seo, Yoon \& Yoon, 2016; Özduran \& Tanova, 2017). A leader with a transformational mindset contributes to the values of organizational citizenship behaviour in social responsibilities such as individuals, societies and organizations (Allen et al., 2017). Transformational leadership is interconnected with employees' extra-role behaviour and creates a positive outcome to the value of work at the organization (Majeed et al., 2017). Many empirical previous studies found that transformational leadership style is positively associated with OCB (Humphrey, 2012; Jha, 2014; Nasra \& Heilbrunn, 2015; Ismaeelzadeh, Anjomshoa \& Fard, 2016).

According to Humphrey (2012), transformational leadership was found to be negatively associated with organizational citizenship. The authors, although transformational leadership was found to be positively associated with employees' organizational citizenship behaviour (OCB), attempted to expand and integrate previous research on the mediating effects of trust in supervisors and job satisfaction on the relationship between transformational leadership style and organizational citizenship behaviour (OCB). Therefore, this study proposed its hypothesis as follows:

$\mathrm{H}_{2}$ : Transformational leadership is positively significant with organizational citizenship behaviour (OCB)

\section{Relationship between Transformational Leadership, Organizational Citizenship Behaviour $(O C B)$ and Organizational Commitment}

The existing organizational citizenship behaviour (OCB) among employees could contribute to organizational effectiveness and performance (Smith, Organ \& Near, 1983). A study by Hasani et al. (2013) discovered a significant effect of organizational citizenship behaviour (OCB) on organizational commitment, which included all staff of physical education offices in the provinces of Kurdistan, Kermanshah, West Azerbaijan and Hamadan in Iran. The study selected 293 individuals by referring to the table by Krejcie and Morgan (1970). The study found a significant relationship between OCB and staff organizational commitment, including 
affective commitment, continuance commitment and normative commitment at four physical education offices in Iran (Hasani et al., 2013).

According to Baron and Kenny (1986), the mediator is the third variable that acts as a mediator between the independent and dependent variables influenced by the independent variable to influence the dependent variable. In this study, OCB considered the mediating mechanism as OCB has a role in establishing the relationship between related and construct development (Agarwal, 2016). OCB can be supported by leadership as a predictor variable in which the leadership style of leaders applied affects the development of organizational commitment and OCB in the organization (Hasani et al., 2013). There has been limited study on the influence of transformational leadership and organizational commitment mediated by OCB. Most of the previous researchers have studied the relationship between transformational leadership and organizational commitment with the mediating role of several variables. As such, it was mediated by leader-member exchange (Shiva \& Suar, 2010); empowerment (Ismail, Mohamed, Sulaiman, Mohamad \& Yusuf, 2011); gender (Verma \& Krishnan, 2013); pride in being a follower of the leader (Chan \& Mak, 2014); organizational culture (Shim \& Hoover, 2015); organizational culture (Chrusciel, Wolfe, Hansen, Rojek \& Kaminski, 2015); psychological empowerment (Avolio, Zhu, Koh \& Bhatia, 2004; Kim \& Shin, 2017); perceived social responsibility and organizational identification (Allen et al., 2017). The previous empirical studies were interested in applying OCB as the outcome of organizational commitment in the similar construct variables in this study, including the study by Han, Seo, Yoon and Yoon (2016); Kariuki and Kiambati (2017); Lee et al. (2018); Akoto, Mosley, Assad, Perkins, Thiagarajan and Stammerjohan (2019); Fazriyah, Hartono \& Handayani, (2019). Therefore, this study proposed its hypothesis as follows:

$\mathrm{H}_{3}$ : The organizational citizenship behaviour (OCB) is positively significant with organizational commitment

$\mathrm{H}_{4}$ : The organizational citizenship behaviour (OCB) mediates the relationship between transformational leadership and organizational commitment

\section{The Proposed Conceptual Model}

Aiming to broaden the existing literature on transformational leadership, organizational commitment and OCB, the proposed model in this study is intended to do so in three ways. The relationship between transformational leadership as an independent variable and organizational commitment as a dependent variable is explained by the model proposed in this article. Between these two constructs, OCB serves as a go-between. Based on the review of pieces of literature, the proposed model is presented in the following Figure 1. 


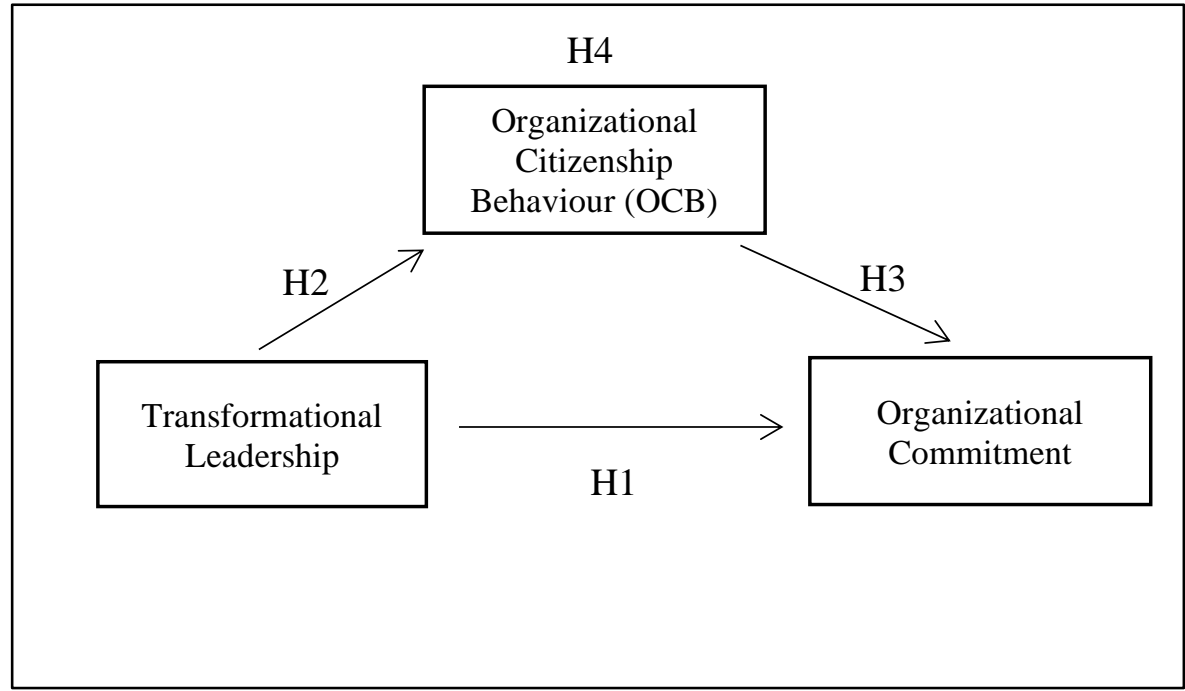

Figure 1: The Proposed Conceptual Model

\section{Limitations and Future Directions}

This paper attempts to fill a significant gap in the field of organizational behaviour studies. According to the framework presented in this paper, transformational leadership has an impact on organizational commitment and OCB. Leaders' knowledge was greatly enhanced by the proposed conceptual model presented in this paper; the first attempt considered the influence of transformational leadership on organizational commitment and OCB in an organization. Furthermore, leaders must place a strong emphasis on the importance of employee commitment, as well as on factors that contribute to increased organizational commitment to achieve high levels of employee retention and performance (Porter, 2014). Additionally, this framework took into account the mediating effect of organizational commitment on the influence of transformational leadership. However, there was a significant limitation to the study's main focus. It was limited in scope when compared to other types of leadership styles in terms of organizational commitment and OCB. Furthermore, since this study only used a small integration model, it was not possible to investigate all of the mechanisms that influence organizational commitment. As a result, all of these concepts can be used as useful topics for future research and literature extensions.

\section{References}

Abouraia, M. K., \& Othman, S. M. (2017). Transformational Leadership, Job Satisfaction, Organizational Commitment, and Turnover Intentions: The Direct Effects among Bank Representatives. American Journal of Industrial and Business Management, 7, 404423. https://doi.org/10.4236/ajibm.2017.74029

Akoto, E. O., Mosley, A. L., Assad, J.-C., Perkins, S., Thiagarajan, P., \& Stammerjohan, C. A. (2019). Economic Dependency on Work: Testing the Direct and Indirect Effects on Commitment and Citizenship in a Volatile Economy. American Journal of Business, 10(1), 96-109.

Al Zefeiti, S. M. B. (2017). The Influence of Transformational Leadership Behaviours on Organizational Commitment in Omani Governmental Organizations. International Journal of Business and Management, 12(4), 111-122. https://doi.org/10.5539/ass.v13n3p102 


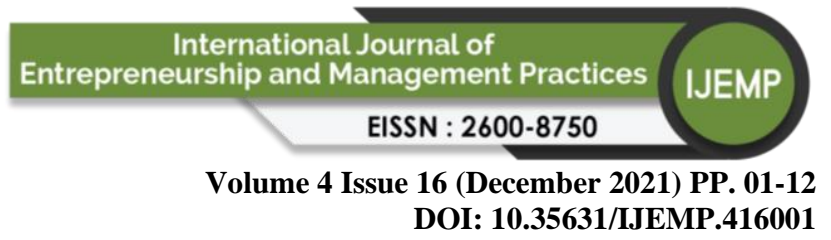

Allen, G. W., Attoh, P. A., \& Gong, T. (2017). Transformational leadership and affective organizational commitment: mediating roles of perceived social responsibility and organizational identification. Social Responsibility Journal, 13(3), 585-600. https://doi.org/10.1108/SRJ-11-2016-0193

Allen, G. W., Attoh, P. A., \& Gong, T. (2017). Transformational leadership and affective organizational commitment: mediating roles of perceived social responsibility and organizational identification. Social Responsibility Journal, 13(3), 585-600. https://doi.org/10.1108/SRJ-11-2016-0193

Allen, N. J., \& Meyer, J. P. (1990). Organizational Commitment-Allen-Meyer (1990).pdf. Journal of Occupational Psychology.

Alparslan, A. M., \& Can, A. (2015). The Antecedents of Extra-Role Organizational Behaviors: A Qualitative Research on Soldiers. Journal of Business Research Turk, 7(1), 26-42.

Andrew, A. (2017). Employees' Commitment and Its Impact on Organizational Performance. Asian Journal of Economics, Business and Accounting, 5(2), 1-13. https://doi.org/10.9734/ajeba/2017/38396

Avolio, B. J., Zhu, W., Koh, W., \& Bhatia, P. (2004). Transformational leadership and organizational commitment: mediating role of psychological empowerment and moderating role of structural distance. Journal of Organizational Behavior, 25, 951968. https://doi.org/10.1002/job.283

Bakar, R. A. (2013). Understanding Factors Influencing Employee Engagement : A Study of the Financial Sector in Malaysia

Bernama-https://www.ismaweb.net/2018/06/29/hanya-profesional-akan-ketuai-pengurusanglc-p

Boardman, A. E., Vining, A. R., \& Weimer, D. L. (2016). The long-run effects of privatization on productivity: Evidence from Canada. Journal of Policy Modeling, 38(6), 10011017. https://doi.org/10.1016/j.jpolmod.2016.04.002

Bright, J. B. (2018). The relationship between transformational leadership behaviours and employee engagement and turnover intent. ProQuest Dissertations and Theses.

Buda, A. A., \& Ling, Y.-L. (2017). The Relationship Between Transformational Leadership and Organizational Commitment in Polytechnic Kuching Sarawak. Malaysian Online Journal of Educational Management (MOJEM), 5(4), 35-46.

Buil, I., Martínez, E., \& Matute, J. (2019). Transformational leadership and employee performance: The role of identification, engagement and proactive personality. International Journal of Hospitality Management, 77, 64-75. https://doi.org/10.1016/j.ijhm.2018.06.014

Chan, S. C. H., \& Mak, W. M. (2014). Transformational leadership, pride in being a follower of the leader and organizational commitment. Leadership \& Organization Development Journal Vol., Vol. 35 No, 674-690. https://doi.org/10.1108/LODJ-12-09-0076

Chrusciel, M. M., Wolfe, S., Hansen, J. A., Rojek, J. J., \& Kaminski, R. (2015). Policing : An International Journal of Police Strategies \& Management Article information: International Journal of Police Strategies \& Management, 38(1), 3-23.

Faupel, S., \& Süß, S. (2019). The effect of transformational leadership on employees during organizational change-An empirical analysis. Journal of Change Management, 19(3), 145-166.

Fazriyah, M., Hartono, E., \& Handayani, R. (2019, March). The Influence of Job Satisfaction and Organizational Commitment on Organizational Citizenship Behavior. In International Symposium on Social Sciences, Education, and Humanities (ISSEH 2018). Atlantis Press. 


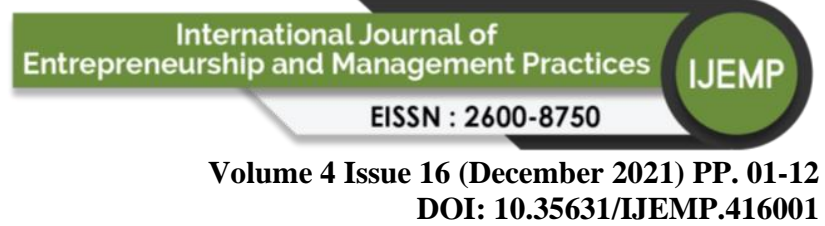

Feizi, M., Ebrahimi, E., \& Beheshti, N. (2014). Investigating the relationship between transformational leadership and organizational commitment of high school teachers in Germi. International Journal of Organizational Leadership, 3, 17-30.

Gao, F. Y. (2011). The effects of transformational leadership on organizational commitment of family employees in Chinese family business. International Conference on Economics, Trade and Development, 7, 43-48.

Gathungu, E. W. M., Iravo, M. A., \& Namusonge, G. S. (2015). Transformational Leadership and Employee's Commitment: Empirical Review. IOSR Journal Of Humanities And Social Science (IOSR-JHSS, 20(7), 1-7. https://doi.org/10.9790/0837-20720107

Gu, C., Wei, Y. D., \& Cook, I. G. (2015). Planning Beijing: socialist city, transitional city, and global city. Urban Geography, 36(6), 905-926.

Gulluce, Ç. A., Kaygin, E., Kafadar, S. B., \& Atay, M. (2016). The Relationship between Transformational Leadership and Organizational Commitment: A Study on the Bank Employees. Journal of Service Science and Management, 9, 263-275. https://doi.org/10.4236/jssm.2016.93033

Gupta, B., Kashyap, V., Hyde, A. M., Lalwani, H., \& Chhabra, I. P. (2019). An Empirical Study of Factors Affecting Organizational Commitment in Banking Sector. International Journal of Computer Sciences and Engineering, 06(09), 116-123. https://doi.org/10.26438/ijcse/v6si9.116123

Hackett, R. D., Wang, A. C., Chen, Z., Cheng, B. S., \& Farh, J. L. (2018). Transformational Leadership and Organizational Citizenship Behaviour: A Moderated Mediation Model of Leader-Member-Exchange and Subordinates' Gender. International Association of Applied Psychology, 1-27. https://doi.org/10.1111/apps.12146

Hameed, A., \& Waheed, A. (2011). Employee development and its affect on employee performance a conceptual framework. International journal of business and social science, 2(13).

Hamidi, S. Z., \& Salimi, S. B. (2015). Considering The Relationship Between Transformational Leadership And Organizational Commitment With Citizenship Behavior (Case study: Staff Of Branches of Maskan Bank in Guilan Province-Iran). Kuwait Chapter of Arabian Journal of Business and Management Review, 5(4), 42-54.

Han, S. H., Seo, G., Yoon, S. W., \& Yoon, D.-Y. (2016). Transformational leadership and knowledge sharing. Journal of Workplace Learning, 28(3), 130-149. https://doi.org/10.1108/JWL-09-2015-0066

Hasani, K., Boroujerdi, S. S., \& Sheikhesmaeili, S. (2013). The effect of organizational citizenship behavior on organizational commitment. Global Business Perspectives, 1(4), 452-470. https://doi.org/10.1007/s40196-013-0026-3

Humphrey, A. (2012). Transformational Leadership and Organizational Citizenship Behaviors: The Role of Organizational Identification. Psychologist-Manager Journal, 15(4), 247268. https://doi.org/10.1080/10887156.2012.731831

Ishak, S. (2011). Syarikat berkaitan Kerajaan Negeri-kepentingan lepas dan cabaran masa hadapan $=$ State Government link companies-past performance and future challenges. Akademika, 81(1), 51-62. Retrieved from http://journalarticle.ukm.my/1885/

Ismail, A., Mohamed, H. A.-B., Sulaiman, A. Z., Mohd Hamran, M., \& Yusuf, M. H. (2011). An Empirical Study of the Relationship between Transformational Leadership , Empowerment and Organizational Commitment. Business and Economics Research Journal, 2(1), 89-107.

Jamaludin, N. D., Sanusi, Z. M., \& Kamaluddin, A. (2015). Board Structure and Earnings Management in Malaysian Government Linked Companies. Procedia Economics and Finance, 28, 235-242. https://doi.org/10.1016/S2212-5671(15)01105-3

Copyright $\odot$ GLOBAL ACADEMIC EXCELLENCE (M) SDN BHD - All rights reserved 
Jones, A. L. (2014). Generational Cohort Differences in Types of Organizational Commitment Among Nurses in Alabama. PhD Thesis. https://doi.org/10.1111/j.14678616.2008.00521.x Malik

Kara, D. (2012). The Effects of Managers Transformational Leadership Style on Employees Organizational Commitment. International Journal of Academic Research in Accounting, Finance and Management Sciences, 2(1), 16-24. Retrieved from www.hrmars.com/journals

Kariuki, A., \& Kiambati, K. (2017). Empowerment, Organizational Commitment, Organization Citizenship Behavior and Firm Performance. Management Studies, 5(4), 290-300. https://doi.org/10.17265/2328-2185/2017.04.003

Khasawneh, S., Omari, A., \& Abu-Tineh, A. M. (2012). The Relationship between Transformational Leadership and Organizational Commitment: The Case for Vocational Teachers in Jordan. Educational Management Administration and Leadership, 40(4), 494-508. https://doi.org/10.1177/1741143212438217

Kim, S., \& Shin, M. (2017). Transformational leadership behaviors, the empowering process, and organizational commitment: investigating the moderating role of organizational structure in Korea. The International Journal of Human Resource Management, 1-25. https://doi.org/10.1080/09585192.2016.1278253

Kowalski, P, M. Büge, M. Sztajerowska \& M. Egeland (2013), "State-Owned Enterprises: Trade Effects and Policy Implications", OECD Trade Policy Paper, No. 147, Paris: OECD.

Kuncoro, W., \& Wibowo, G. (2019). The Increase of Organizational Citizenship Behaviour (OCB) Through Islamic Work Ethics, Affective Commitment, and Organizational Identity. International Business Research, 12(2), 181-190. https://doi.org/10.5539/ibr.v12n2p181

Lee, Y. H., Woo, B., \& Kim, Y. (2018). Transformational leadership and organizational citizenship behavior: Mediating role of affective commitment. International Journal of Sports Science and Coaching, 13(3), 1-10. https://doi.org/10.1177/1747954117725286

Lin, J. Y., Fang, C., \& Li, Z. (1998). American Economic Association Competition , Policy Burdens, and State-Owned Enterprise Reform Author ( s ): Justin Yifu Lin , Fang Cai and Zhou Li Source: The American Economic Review, Vol . 88 , No . 2 , Papers and Proceedings of the Hundred and Tenth. The American Economic Review, 88(2), 422427.

Lin, L., \& Shiqian, W. (2018). The Mediating Effect of Organizational Commitment on Leadership Type and Job Performance. Journal of World Economic Research, 7(1), 1420. https://doi.org/10.11648/j.jwer.20180701.12

Lo, M. C., Ramayah, T., Min, H. W., \& Songan, . (2010). The relationshi between leadershi styles and organizational commitment in Malaysia: Role of leader-member exchange. Asia acific Business Review, 16(1-2), 79-103. htts://doi.org/10.1080/13602380903355676

Luo, A., Guchait, P., Lee, L., \& Madera, J. M. (2019). International Journal of Hospitality Management Transformational leadership and service recovery performance: The mediating effect of emotional labor and the influence of culture. International Journal of Hospitality Management, 77, 31-39. https://doi.org/10.1016/j.ijhm.2018.06.011

Majeed, N., Ramayah, T., Mustamil, N., Nazri, M., \& Jamshed, S. (2017). Transformational leadership and organizational citizenship behavior : Modeling emotional intelligence as mediator. Management and Marketing. Challenges for the Knowledge Society, 12(4), 571-590. https://doi.org/10.1515/mmcks-2017-0034. 
Menon, J. (2017). Government-Linked Companies: Impacts on the Malaysian Economy. Policy IDEAS, 45, 1-26.

Najid, N. A., \& Rahman, R. A. (2011). Government ownership and performance of Malaysian government-linked companies. International Research Journal of Finance and Economics, (61), 42-56. Retrieved from http://www.scopus.com/inward/record.url?eid=2-s2.079251648182\&partnerID=40\&md5=efee3abc56a285739d8133f677fd5640

Nasra, M. A., \& Heilbrunn, S. (2014). Transformational leadership and organizational citizenship behavior in the Arab educational system in Israel: The impact of trust and job satisfaction. Educational Management Administration and Leadership, 44(3), 380 396. https://doi.org/10.1177/1741143214549975

Ng, T. W. H., \& Feldman, D. C. (2011). Affective organizational commitment and citizenship behavior: Linear and non-linear moderating effects of organizational tenure. Journal of Vocational Behavior, 79, 528-537. https://doi.org/10.1016/j.jvb.2011.03.006

Njoroge, D. (2015). Transformational leadership style and organizational commitment: the moderating effect of employee partcipation. The Strategic Journal of Business \& Change Management, 2(6), 94-107.

Nordin, N. (2012). Assessing Emotional Intelligence, Leadership Behaviour and Organizational Commitment in a Higher Learning Institution. Procedia - Social and Behavioral Sciences, 56, 643-651. https://doi.org/10.1016/j.sbspro.2012.09.699

Okeke, R. C., \& Nnamani, D. O. (2018). Worker Commitment and Organizational Citizenship Behaviour in the Age of Wisdom: Critical Evaluations. International Letters of Social and Humanistic Sciences, 81, 13-21. https://doi.org/10.18052/www.scipress.com/ILSHS.81.13

Özdemir, Y., \& Ergun, S. (2015). The Relationship between Organizational Socialization and Organizational Citizenship Behavior: The Mediating Role of Person-Environment Fit. Procedia - Social and Behavioral Sciences, 207, 432-443. https://doi.org/10.1016/j.sbspro.2015.10.113

Özduran, A., \& Tanova, C. (2017). Manager mindsets and employee organizational citizenship behaviours. International Journal of Contemporary Hospitality Management, 29(1), 589-606. https://doi.org/10.1108/IJCHM-03-2016-0141

Podsakoff, P. M., Mackenzie, S. B., Moorman, R. H., \& Fetter, R. (1990). Transformational Leader Behaviors and Their Effects on Followers' Trust in Leader, Satisfaction, and Organizational Citizenship Behaviors. Leadership Quarterly, 1(2), 107-142.

Porter, J. A. (2014). The relationship between transformational leadership and organizational commitment in nonprofit long term care organizations: The direct care worker perspective (Doctoral dissertation, Creighton University)

Putrajaya Committee on GLC High Performance. (2015). Glc Transformation Programme Graduation Report.

Robertson, J. L., \& Barling, J. (2017). Toward a new measure of organizational environmental citizenship behavior. Journal of Business Research, 75, 57-66. https://doi.org/10.1016/j.jbusres.2017.02.007

Said, J., Jaafar, N. H., \& Atan, R. (2015). Assessing accountability in government linked companies: An empirical evidence. International Business Management, 9(4), 460469. https://doi.org/10.3923/ibm.2015.460.469

Selamat, N., Nordin, N., \& Adnan, A. A. (2013). Rekindle Teacher's Organizational Commitment: The Effect of Transformational Leadership Behavior. Procedia - Social and Behavioral Sciences, 90, 566-574. https://doi.org/10.1016/j.sbspro.2013.07.127 
Shim, H. S., Jo, Y., \& Hoover, L. T. (2015). Police transformational leadership and organizational commitment: mediating role of organizational culture. Policing: An International Journal of Police Strategies \& Management, 38(4), 754-774. https://doi.org/10.1108/PIJPSM-05-2015-0066

Shiva, M. S. A., \& Suar, D. (2010). Leadership, Lmx, Commitment and Ngo Effectiveness: Transformational Leadership, Leader-Member Exchange, Organizational Commitment, Organizational Effectiveness and Programme Outcomes in NonGovernmental Organizations. International Journal of Rural Management (Vol. 6). https://doi.org/10.1177/097300521100600106

Shukla, A., \& Pandey, S. (2019). Study of Organizational Commitment in Relation to Emotional Labour. International Journal of Management Studies, VI(1(7)), 33. https://doi.org/10.18843/ijms/v6i1(7)/04

Sivasakthi, K., \& Selvarani, A. (2015). The Causal Relationship Between Job Attitude and Organizational Citizenship Behavior in Yashimarine Logistics (P) Ltd., At Chennai. International Journal of Management, 6(1), 373-384.

Verma, S. P., \& Krishnan, V. R. (2013). Transformational Leadership and Follower' s Organizational Commitment : Role of Leader's Gender. NMIMS Management Review, $23,91-112$.

Wang, Z., Xu, S., Sun, Y., \& Liu, Y. (2019). Transformational leadership and employee voice: an affective perspective. Frontiers of Business Research in China, 13(1). https://doi.org/10.1186/s11782-019-0049-y

Whittington, L. J., \& Galpin, T. J. (2010). The engagement factor: building a high-commitment organization in a low-commitment world. Journal of Business Strategy, 31(5), 14-24. https://doi.org/10.1108/02756661011076282

Yao, T., Qiu, Q., \& Wei, Y. (2019). Retaining hotel employees as internal customers: Effect of organizational commitment on attitudinal and behavioral loyalty of employees. International Journal of Hospitality Management, 76, 1-8. https://doi.org/10.1016/j.ijhm.2018.03.018

Yin, O. S., Hee, O. C., Mahmood, R., \& Hamli, M. S. H. (2018). Organizational Citizenship Behaviour and Turnover Intention among Generation $\mathrm{Y}$ in Malaysia. International Journal of Academic Research in Business and Social Sciences, 8(7), 690-701. https://doi.org/10.6007/ijarbss/v8-i7/4412

Zhang, Y., Guo, Y., \& Newman, A. (2017). Identity judgements, work engagement and organizational citizenship behavior: The mediating effects based on group engagement model. Tourism Management, 61, 190-197. https://doi.org/10.1016/j.tourman.2017.01.005 